\title{
Struggle and Survival in Cultural Clash: A Case Study of Pecola in The Bluest Eye
}

\author{
Bin Yuan ${ }^{1}$ \\ ${ }^{1}$ Foreign Language Department, Chengdu Sport Institute, Chengdu, China \\ Correspondence: Bin Yuan, Foreign Language Department, Chengdu Sport Institute, Chengdu, China. E-mail: \\ wyuanbin@sina.com
}

Received: January 10, 2018 Accepted: February 2, 2018 Online Published: February 8, 2018

doi:10.5539/ells.v8n1p104 URL: https://doi.org/10.5539/ells.v8n1p104

\begin{abstract}
Toni Morrison is not only one of the Afro-American writers who focus on the clash between black culture and the white mainstream culture in the United States as well as the marginalized existence of the blacks, but more importantly a unique Afro-American woman writer who goes beyond the simplistic dichotomies of the black male literary tradition and explores the root of the tragedy of the blacks in the mainstream society. Based on textual analysis of her first novel The Bluest Eye and a case study of Pecola, a main character in this novel and actually a victim and scapegoat, this paper, with the painful truth that Pecola's tragedy results not just from the denial and rejection of the mainstream society, but more significantly, from the blind identification of some blacks in the mainstream culture, and their incompetence to cherish their own culture and identity, aims at exploring hope in the tragic story, and suggesting how blacks can struggle to survive so as to extend their heritage and values.
\end{abstract}

Keywords: The Bluest Eye, Pecola, identification, tragedy, Toni Morrison

\section{Introduction}

Afro-American literature is born from and develops with cultural clash and identification, and it is characterized by a tension of acculturation and separation since Afro-American writers are faced with both cultural identification in the mainstream for survival, and the necessity of keeping aloof from the mainstream to maintain their own tradition. Since 1970s, a remarkable efflorescence of Afro-American literary works has been produced, mostly by African American women writers, which, in fact, accelerates the reshaping of American literary canon. Toni Morrison is, undoubtedly, one of them, and as a writer "who, in novels characterized by visionary force and poetic import, gives life to an essential aspect of American reality" (Morrison, 2004, p. 2), she won the Nobel Prize for literature in 1993.

As a woman and an Afro-American, Toni Morrison goes beyond the simplistic dichotomies of the black male literary tradition in which the world is typically divided into black/white, good/evil, virgin/whore, self/other, male/female paradigms, and explores the history, tradition and fate of black people in the mainstream society. Moreover, she, different from many other major Afro-American writers, does not adopt the common implicit/explicit method of social protest, but instead makes a thorough exploration of the meaning and value of sustaining black tradition and culture. And her writing focuses on the marginalized black women, which are, in a large sense, ignored by the majority of Afro-American writers. In fact, when Morrison begins writing in the 1960s and 1970s, there are few books about Afro-American women and their experiences; their voices are seldom heard just as Jan Furman (1996, p. 6) points out that "this person, this female, this black did not exist center-self."

The Bluest Eye is Morrison's first novel and is also the best one that exemplifies her attitude about Afro-American women and their dilemma in the mainstream society of the United State. The novel tells a story of Pecola, a marginalized little black girl who is made a victim and scapegoat by both the whites who oppress and make norms for the blacks and the blacks who blindly identify themselves in the white mainstream culture at the cost of their own racial identity. Through her tragic story, what Morrison wants to reveal is that the psychological disintegration of Pecola results not just from the rejection of white mainstream culture, but more importantly, from the blind identification of the black community and the loss of their own heritage and values. With this painful truth, Morrison goes on exploring hope in the tragic story, and suggests how some blacks 
struggle to survive so as to extend their heritage and values.

\section{Discussion}

\subsection{The Rejection of the Mainstream Culture}

In The Bluest Eye, Morrison's focus is on Pecola, a 12 year-old little black girl, who lives in a society in which white norms are above all others. Pecola attributes her ugliness to the lack of a pair of blue eyes, with which, she believes that she can find a shelter from her parents' cruelty, neighbors' indifference, friends' ridicule, and in fact, the neglect of the community and society.

The novel presents 3 possible family situations: an idealized white family (the Geraldine's), a warm black family (the M'Dear's), and a self-denial bottom family (the Breedlove's), which are actually the true representation of family models in the society. (Rice, 1996, p. 3) The transmutation from the idealized to the bottom is Morrison's criticism of the white mainstream culture for the split-up black community between some blacks who blindly identify themselves into the white mainstream society by abandoning their own tradition and some others who are still clinging to their own culture and identity. In fact, according to W.E.B. Du Bois (1999), the blacks are born with a veil and gifted with second-sight in this American world. They look at their selves through the eyes of the whites. That is the root of their blind identification, and the root of Pecola's tragedy as well.

In this sense, Pecola's tragedy - her unloving childhood, her repudiation by nearly everyone she encounters, and finally the complete disintegration of self-is doomed at the very beginning since "they (the Breedloves)... believed they were ugly... their ugliness was unique," and they cannot do anything but "accepted it without question...took the ugliness in them hands, threw it as a mantle over them, and went about the world with it," and Pecola "hid behind hers. Concealed, veiled, eclipsed-peeping out from behind the shroud very seldom, and then only to yearn for the return of her mask." (Morrison, 1970, pp. 34-35) Unfortunately, Pecola's tragedy is not just a tragedy of Pecola, or her family; it mirrors the tragedy of the whole black community where a lot of blacks try to separate themselves in "body and mind" from all that suggests their African origin and defines their African identity.

Pecola's desire for a pair of blue eyes results not only from her own awareness of her ugliness, from the recognition of her ugliness by her parents and the black community, but also from a her false conviction that a pair of blue eyes, symbolically as some kind of social norm and judgement, would make herself different and cared and loved by anyone; therefore, "Long hours she sat looking in the mirror, trying to discover the secret of the ugliness," and she "each night, without fail, prayed for blue eyes," (Ibid, p. 40). Unfortunately, what Pecola finds in the mirror is not a healthy psyche and a complete identity, but a distorted self, and the denial as well as rejection of the mainstream society. Therefore, Pecola is caught by a loss of self and a sense of rootlessness, and finally mentally disintegrated with an illusion that she already has a pair of blue eyes and she gets what she dreamed of. Obviously, this pair of blue eyes symbolizes the white mainstream culture which defines beauty and ugliness; with the blue eyes, Pecola and actually the whole black community watch the world from the perspective of the whites.

Pecola is ignored at school by both teachers and classmates. She is the only member of her class who sits alone at a double desk. The storekeeper who sells Mary Jane candies to Pecola avoids touching her hand when she pays, and barely disguises his contempt for her:

"She looks up at him and sees the vacuum where curiosity ought to lodge.... The total absence of human recognition - the glazed separateness.... It has an edge; somewhere in the bottom lid is the distaste... The distaste must be for her, for her ugliness... and it is the blackness that accounts for, that creates, the vacuum edged with distance in white eyes". (Ibid, p. 42)

Obviously, in Pecola, what we perceive is the distortion and dislocation of a confused self created by the internalization of white norms and the white mainstream culture.

\subsection{The Blind Identification of the Blacks in the Community}

Indeed, the rejection of the the mainstream culture is not the only root of Pecola's tragedy; the blind identification of the blacks in the white mainstream society counts a lot. Her parents and the blacks in her community all believe she is ugly, which strengthens the conviction of her ugliness and contributes to her self-denial, and final mental disintegration. In The Bluest Eye, Morrison gives a detailed analysis of how her parents accept their own ugliness "It was as though some mysterious all-knowing master had given each on a cloak of ugliness to wear, and they had each accepted it without question." (Morrison, 1970)

Therefore, responsibility must be shared by the blacks in the community who negate their own unique physical 
and cultural identity during the process of identification and the internalization of the white mainstream culture, and who deliberately make Pecola a victim and scapegoat of their blind identification. By doing so, the collective catharsis is finally accomplished in the most vulnerable character Pecola: "All of us - all who knew her-felt so wholesome after we cleaned ourselves on her." (Ibid, p. 161) With a scapegoat to shoulder their sufferings and humiliation vicariously, the blacks in the community make themselves feels better.

As a result, little black boys in the community deride her without consideration of the color of their own skins. In the school, the teachers try not glance at, and in fact despise Pecola since she is seen as a reminder of their past and origin that they try to forget and escape. They are using Pecola as the vehicle through which they can pour their shame and frustration. The light-complexioned Maureen distinguishes between her lighter skin and Pecola's much darker skin by claiming "I am cute! And you are ugly! Black and ugly black e mos. I am cute!" (Ibid, p. 56) without understanding that her depreciation of the dark-skinned blacks actually represents her devaluation of her own heritage and tradition. Geraldine distinguishes her family from other blacks by calling her family "neat and quiet colored people", not "dirty and loud niggers," (Ibid, p. 67) and she drives Pecola out of her house as the black-skinned Pecola reminds her of all that she wants to deny and escape. Ironically, Geraldine continuously puts "Jergens Lotion on [her son's] face to keep the skin from becoming ashen" (Ibid, p. 68), because she is afraid that the ashen color of her son's skin will reveal himself as a "nigger".

The preacher in the community Church is also responsible for the tragedy of Pecola who comes to him and seeks for help, but only receives cheat. Church tries to keep himself away from the black community so as to merge into the mainstream society, but remains an outsider all the time. He cheats Pecola by asking Pecola to poison a dog he hates, and declaring that the struggling of the dog suggests that she gets the blue eyes. The truth is though the blacks in the community attempt to imitate the white, and try, in vain, to change the color of their skin and their authentic identity, they never succeed in hiding the inner dislocation and fully accommodating to the white mainstream society even at the cost of their blackness.

Even her parents, Cholly and Pauline Breedlove, jointly contribute to Pecola's tragedy. In fact, Back in the south, Pauline is naive and simple; she lives a happy and content life with family protection and love. However, this sense of simple happiness is crushed in the obstetrical hospital where she is seen as an animal when she gives birth to Pecola. Later as she arrives the north, the old good days are gone for ever and she receives ridicules for her southern dialect and unstylish appearance; she begins to complain about her husband and her daughter Pecola, and gradually negate her own racial identity. Unfortunately, the movie theaters where she usually sits in the darkness can not give her any comfort, but a false sense of happiness, and those blacks on the screen are always stupid and funny fools, or sly women servants. These experiences, in a large sense, can not help build a shelter for Pauline, but instead, strengthen her inferiority. Her awkward imitations of the movie stars, and her extravagant spending on dressing and haridos do not work too. As a result, frustrated and disappointed, she gradually abandons her family and Pecola, and transfers her love to the kids of the family where she works as a servant, which indeed partly adds up to her own dislocation and Pecola's spiritual disintegration during the process of her blind identification of the white mainstream society and culture. The more she integrates into the family of her white master, the more she neglects her own family. Pecola's father Cholly is to be blame too, who suffers a painful experience of being abandoned by his mother, rejected by his father, discriminated and humiliated by the whites, and who is always haunted by frustration and mental disorder. Finally, he abandons his duties and responsibilities for his family, and treats her daughter Pecola with twisted psychopathic love (he rapes Pecola), which inevitably accelerates Pecola's spiritual disintegration.

As a result, at home or in the black community, Pecola never secures a shelter, but rejected and negated by both the white mainstream society and the black community, so she has to cast her fate on something she can never get, and finally she is abandoned by her parents, the blacks in the community and the white society. Therefore, the root of Pecola's tragedy is not just the rejection of the white mainstream culture, but more importantly, the blind identification of the blacks in the community, during which Pecola is made a victim and scapegoat of their abandonment of black cultural identity.

\subsection{Struggle and Survival in the Cultural Clash}

Of course, the tragedy of Pecola is not everything in the novel. Through the stories of the three prostitutes who are named "Poland", "China" and "Maginot Line" with symbolic meaning of struggle against power, and who extend genuine love to Pecola, and through the warm M'Dears and their responsibilities for the black community, Morrison depicts a group of blacks who adhere to their own culture and identity, and manage to survive so as to demonstrate her hope for the blacks. After all, Morrison, in an interview, tells her audience that her works come from pleasure of hope, not frustration of hopelessness, and the purpose of her literature is "to identify those 
things in the past that are useful and those things that are not," and "to give nourishment"(LeClair, 1994, p. 121).

The home of the three prostitutes is the place where Pecola frequently visits, and where Pecola can find some warmth and care. Different from other blacks in the community, the three prostitutes never thought that Pecola is ugly and dirty; they are honest, and show contempt for authority and men; they choose to live their own life without caring about the opinions of others. They laugh, drink and swear. Although avoided by the town's respectable folks, they are the people who provide true love to Pecola. They express their maternal tenderness to Pecola in the various lovely nicknames they give her: Dumplin, Puddin, Chicken, and Honey. It is in their house, not in her own home that Pecola can find a sense of security and plenty of laughter. Clearly, in such a black community where most of the blacks are self-denied and self-exiled, the three prostitutes represent and confirm the value of the black heritage and culture.

The warm M'Dears live a different life in the black community, which is characterized by love and responsibility In The Bluest Eye, Claudia, more than once, recalls affectionately her mother's warm hands and how her mother covers her up in the midnight, and feels that her mother's love is as thick as Alaska syrup. It is this love and care of the family that gives the kids dignity and self-confidence, so they never give up their hopes and beliefs, and always keep their healthy psyche. And they never judge themselves with the white norms and culture, and they are able to spare sympathy to others. M'Dear is a timeless magician, whose magic always bring cure to the blacks in the community. Unlike many other blacks, the M'Dear couple never abandon their responsibilities for their family and the black community; they love black music, a cure for the spiritual hurt of the blacks, and they still retain the cultural tradition of the blacks. It is the M'Dears who take Pecola in when Cholly burns the house even if she is a heavy burden to the poor family.

In The Bluest Eye, the narrator of the story, a young black girl called Claudia M'Dear who is part of a poor but loving black family in Lorain, Ohio, in the 1940s, is another exception. Claudia has attempted to do something for her friend Pecola, the girl raped by her own father. Planting the seeds of marigold in the earth, Claudia and Frieda hope that if they say the right words over those seeds, "they [the seeds] would blossom, and everything would be all right". (Morrison, 1970, p. 164) Later, Claudia realizes that "this soil is bad for certain kinds of flowers. Certain seeds it will not mature. Certain fruit it will not bear." (Ibid, p. 164) Symbolically, Claudia's words serve as a scathing critique of the hostile environment, which, in fact, leads to the tragic fate of Pecola and the whole black community. Unlike Pecola, Claudia notices that little white girls and little black girls are treated differently, and she adopts an attitude of rejection towards the white mainstream culture. Claudia's response to her Christmas present, a blue-eyed baby doll, is not to love it, but to hate it, and even to take it apart for its "dreadful and humiliating absence of dirt' and "the irritable, unimaginative cleanliness". (Ibid, p. 146) By perversely loving dirt while detesting cleanliness, Claudia actually attempts to affirm the worth of the blacks.

\section{Conclusion}

The Bluest Eye comes out in the 1970s, a decade when the black literature begins to put an emphasis on the function of the black community in the formation and maintenance of black identity and also the positive attitudes that African Americans should hold regarding their own ethnic group and their culture. Morrison must be aware how the recovering of the self-confidence and their own racial identity of African Americans has led to their recognition in American society. In this novel, what can be perceived clearly is the emphasis on the importance of African heritage and values for African Americans.

Therefore, the tragedy of Pecola, with an evident reason of the corrosion as well as oppression of the white culture, is mainly caused by the blind identification of the blacks themselves in the community, and their inability to sustain their own culture, which explains that when they hear the tragedy of Pecola, they feel disgusted, outraged, or even excited by the story instead of extending their sympathy to the victim. In fact, the whole black community is indifferent, "We were so beautiful when we stood astride her ugliness. Her simplicity decorated us, her guilt sanctified us, her pain make us glow with health, her awkwardness make us think us believe we were eloquent. Her poverty kept us generous. Even her waking dreams we used - to silence our own nightmares. And she let us, and thereby deserved our contempt...." (Morrison, 1970, p. 142) In this sense, Pecola's tragedy is not her own tragedy, but a tragedy of the whole black community, and the whole black race in the white mainstream society.

Hopefully, just as her comments on The Bluest Eyes, "I'm interested in survival—who survives and who does not, and why - and I would like to chart a course that suggests where the dangers and where the safety might be", (Tate, 1992, p. 145) what Morrison, through the tragic story of Pecola, wants to reveal is a sense of hope and how to identify between two cultures so as to survive in the white mainstream society as well as how to cherish their native culture. Therefore, the purpose of Morrison to depict the tragedy of Pecola and the disunity inside 
the black community is to encourage black people to move from disunity to unity, from self-interest to communal interest, and most importantly from self-denial to self-regard.

\section{Acknowledgments}

Sincere gratefulness goes to the authors of the references for their sparkling ideas to inspire the research, and finally the writing of the paper, my wife CHENG Zhenzhen for proofreading of the paper, and my friend LI Hang for his recommendation and encouragement.

\section{References}

Dubois, W. E. B. (1999). The Souls of Black Folk. New York \& London: W. W. Norton \& Company, Inc.

Furman, J. (1996). Toni Morrison's Fiction. Columbia: University of South Carolina Press.

Hu, J. (2007). A Study of the Identity Pursuit of African Americans in Toni Morrison's Fiction. Beijing: Beijing Language and Culture University Press.

LeClair, T. (1994). The Language Must Not Sweat: A Conversation with Toni Morrison. In T. Guthrie (Ed.), Conversation with Toni Morrison. Jackson: University of Mississippi. https://doi.org/10.2307/3042202

Morrison, T. (1970). The Bluest Eye. New York: Washington Square Press.

Morrison, T. (2004). Lecture and Speech of Acceptance, upon the Award of the Nobel Prize for Literature. delivered in Stockkolm on the Seventh of December, Nineteen Huandred and Ninety-Three. New York: Knopf. https://doi.org/10.2307/j.ctt5hjqnj.64

Rice, H. W. (1996). Toni Morrison and the American Tradition. New York: Peter Lang. https://doi.org/10.2307/2901230

Steiner, W. (1992). The Clearest Eye. New York Times Book Review.

Tate, C. (1992). Toni Morrison. In T. Guthrie (Ed.), Conversations with Toni Morrison. University of Mississippi. https://doi.org/10.2307/3042202

\section{Copyrights}

Copyright for this article is retained by the author(s), with first publication rights granted to the journal.

This is an open-access article distributed under the terms and conditions of the Creative Commons Attribution license (http://creativecommons.org/licenses/by/4.0/). 